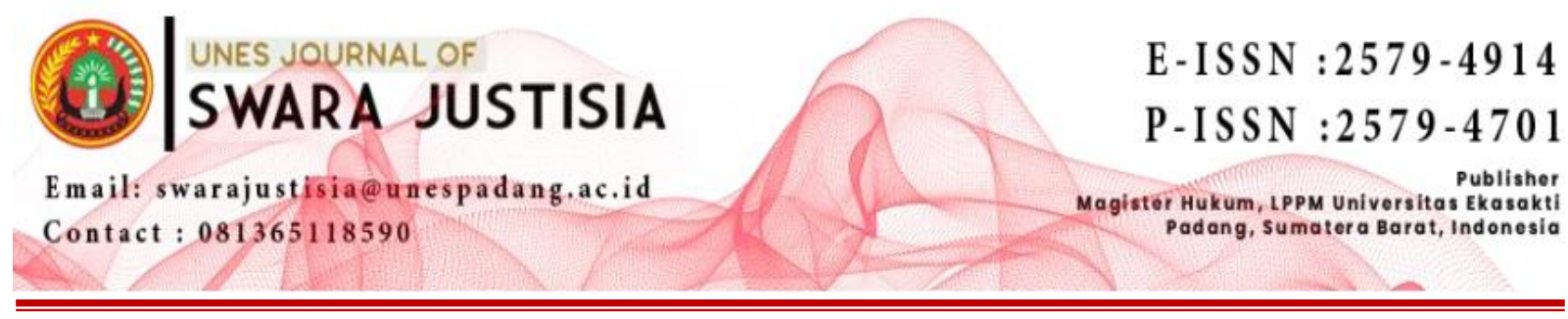

\title{
PENERAPAN PIDANA TERHADAP TINDAK PIDANA PENCABULAN DENGAN KORBAN ANAK
}

\author{
Indra Junaidi \\ Program Magister Ilmu Hukum,Universitas Ekasakti, Padang, Indonesia \\ Email: indrajunaidiadvokat@gmail.com
}

\begin{abstract}
The Criminal Application of the Crime of Morality with Victims of Minors in Decision Number 154/Pid.Sus/2018/PN.Lbb And Decision Number 49/Pid.Sus/2019/PN.Lbb is based on Article 81 (2) of Law Number 35 of 2014 concerning amendments to Law Number 23 of 2002 concerning Child Protection. In Decision Number 154/Pid.Sus/2018/PN.Lbb the punishment imposed is imprisonment for: 8 (eight) years and 6 (six) months, and a fine of Rp. 10,000,000 (ten million rupiah), provided that if the fine is not paid, it will be replaced with imprisonment for 6 (six) months. Meanwhile, in Decision Number 49/Pid.Sus/2019/PN.Lbb the Judge applies a sentence of imprisonment for 7 (seven) years and a fine of Rp. 10,000,000,- (ten million rupiah) provided that if the fine is not paid, it will be replaced with imprisonment for 6 (six) months. Judge's Consideration of Crimes of Morality with Minors Victims In Decision Number 154/Pid.Sus/2018/PN.Lbb, the thing that is considered in the judge's consideration is the fulfillment of the juridical elements as contained in the indicted article. And Decision Number 49/Pid.Sus/2019/PN.Lbb contains sociological considerations. Sociological considerations that are considered by the Judge are that the Defendant's actions violated the norms prevailing in society, both legal norms, moral norms and religious norms and the Defendant admitted his actions. Circumstances mitigating the defendant's behavior in court.
\end{abstract}

Keywords: Crime of Obscenity, Criminal Application, Children

\begin{abstract}
ABSTRAK
Penerapan Pidana Terhadap Tindak Pidana Kesusilaan Dengan Korban Anak Dibawah Umur Pada Putusan Nomor 154/Pid.Sus/2018/PN.Lbb Dan Putusan Nomor 49/Pid.Sus/2019/PN.Lbb adalah berdasarkan Pasal 81 (2) Undang-Undang Nomor 35 tahun 2014 tentang perubahan atas undang undang Nomor 23 Tahun 2002 tentang Perlindungan Anak. Pada Putusan Nomor 154/Pid.Sus/2018/PN.Lbb pidana yang dijatuhkan adalah Penjara selama: 8 (delapan) tahun dan 6 (enam) bulan, dan pidana Denda sejumlah Rp. 10.000 .000 (sepuluh juta ruplah), dengan ketentuan apabila pidana Denda tersebut tidak dibayar maka diganti dengan pidana Kurungan selama 6 (enam) bulan. Sedangkan pada Putusan Nomor 49/Pid.Sus/2019/PN.Lbb Hakim menerapkan pidana berupa pidana penjara selama 7 (tujuh) tahun dan pidana denda sebesar Rp. 10.000.000,- (sepuluh juta rupiah) dengan ketentuan apabila pidana denda tersebut tidak dibayar maka diganti dengan pidana kurungan selama 6 (enam) bulan. Pertimbangan Hakim Terhadap Tindak Pidana Kesusilaan Dengan Korban Anak Dibawah Umur Pada Putusan Nomor 154/Pid.Sus/2018/PN.Lbb hal yang diperhatikan dalam pertimbangan Hakim adalah terpenuhinya unsur yuridis sebagimana terdapat pada pasal yang didakwakan. Dan Putusan Nomor 49/Pid.Sus/2019/PN.Lbb terdapat pertimbangan sosiologis. pertimbangan sosiologis
\end{abstract}


yang diperhatikan Hakim adalah Perbuatan Terdakwa melanggar norma yang berlaku dalam masyarakat, baik norma hukum, norma kesusilaan maupun norma agama dan Terdakwa mengakui perbuatannya. Keadaan yang meringankan Terdakwa bersikap sopan dalam persidangan.

Kata Kunci : Tindak Pidana Pencabulan, Penerapan Pidana, Anak

\section{PENDAHULUAN}

Kejadian kesalahan hendak senantiasa ditemukan dalam kehidupan satu hari hari. Tiap orang dalam kehidupannya tentu hendak senantiasa memiliki kemauan buat penuhi kebutuhannya, bila keinginan hendak perihal itu tidak terkabul hingga dalam diri orang benak yang hendak mencuat yakni mau penuhi kebutuhannya itu meski dengan memercayakan seluruh metode serta apalagi cara-cara yang tidak betul. ${ }^{1}$ Bagi Wirjono Projodikoro sesuatu perbuatan kejahatan merupakan pelanggaran norma-norma dalam 3 aspek hukum lain, ialah hukum awas, hukum ketatanegaraan, serta hukum aturan upaya penguasa, yang oleh pembuat hukum ditanggapi dengan sesuatu ganjaran kejahatan.

Ketela societas ibi ius, dimana terdapat warga disana terdapat hukum yang berarti pula tiap warga mempunyai cara-cara berhukum sendiri yang tidak bisa dipaksakan sedemikian itu saja dari serta oleh bangsa lain. ${ }^{2}$ Bermacam berbagai ketentuan terbuat dengan tujuan buat melindungi sikap orang supaya senantiasa berakhlaq baik, tidak melakukan kehancuran, dan kemaksiatan. Walaupun pada dasarnya orang itu dilahirkan berkecenderungan kepada kebaikan, tetapi sekali-kali orang itu pula memiliki bagian negatifnya ialah senang melakukan kehancuran. Alhasil memunculkan sebagian kasus dengan sesama orang apalagi kepada area di sekelilingnya.

Dalam membagikan batasan-batasan hal kesalahan ini banyak sarjana-sarjana mengemukakan pendapatnya dengan cara teoritis berlainan satu serupa lain, Bonger berkata, kalau kesalahan itu merupakan: "Aksi yang amat anti sosial yang mendapatkan tentangan dengan siuman dari Negeri berbentuk pemberian beban( ganjaran ataupun aksi). ${ }^{3}$ Kesalahan terjalin di tiap ruang serta tempat, durasi serta bangsa. Beliau ialah kejadian kehidupan orang. Upaya yang bisa dicoba merupakan menghindari serta kurangi kesalahan dalam warga. Kesalahan amat berhubungan dengan pemidanaan, karena mereka yang sudah melaksanakan kesalahan sepatutnya di ajukan pada majelis hukum serta dijatuhi kejahatan yang setimpal. ${ }^{4}$

Kesalahan selaku salah satu wujud aksi laris orang yang amat mudarat warga, sebab mengecam norma-norma yang melandasi kehidupan ataupun keteraturan sosial bisa memunculkan ketegangan perseorangan, ataupun ketegangan- ketegangan sosial. Alibi pengakuan kepada keberadaan kesalahan itu sebab, kesalahan ialah wujud aksi laris orang yang amat mudarat warga, semacam kesalahan kesusilaan yang mencakup pemerkosaan, prostitusi, pelecehan intim serta lain-lain. Kesalahan kesusilaan (misdrijven tegen de zeden) ialah kesalahan yang lumayan menemukan atensi digolongan warga, nampak dari seringnya dikabarkan perbuatan kejahatan perkosaan serta prostitusi di media- media elektronik serta

\footnotetext{
${ }^{1}$ Wirjono Projodikoro, Tindak Pidana Tertentu di Indonesia, Refika Aditama, Bandung, 2003, hlm 5.

${ }^{2}$ Suteki, Desain Hukum di Ruang Sosial, Thafa Media, Yogyakarta, 2013, hlm. 165-166.

${ }^{3}$ Hari Saherodji, Pokok-Pokok Kriminologi, Aksara Baru, Jakarta, 1980, hlm. 11.

4 Andi Hamzah, Suatu Tinjauan Ringkas Sistem Pemidanaan di Indonesia, Akademika Pressindo, Jakarta, 1999, hlm 9.
} 
cap. Kemajuan teknologi yang begitu cepat memunculkan problema terkini untuk pembuat Hukum mengenai gimana triknya mencegah warga dengan cara efisien serta berdaya guna kepada ancaman keberkurangan selaku dampak dari masuknya pemikiran serta Kerutinan adat barat hal kehidupan intim di negeri tiap- tiap. Masuknya pemikiran serta Kerutinan adat barat ke Indonesia, bisa memunculkan permasalahan untuk penguasa dalam usahanya buat menjaga keamanan biasa serta menjaga kedisiplinan biasa dalam warga yang bukan tidak bisa jadi bisa pengaruhi dengan cara minus upaya bangsa Indonesia dalam menjaga daya tahan nasional mereka. $^{5}$

Perbuatan kejahatan kesusilaan merupakan seluruh berbagai wujud sikap yang berkonotasi intim yang dicoba dengan cara sepihak serta tidak diharapkan oleh orang yang jadi target alhasil memunculkan respon minus, rasa malu, marah, tersindir pada diri orang yang jadi korban pelecehan intim itu. Pelecehan intim merupakan sikap pendekatan- pendekatan yang terpaut dengan seks yang tidak di idamkan, tercantum permohonan buat melaksanakan seks, serta sikap yang lain yang dengan cara lisan atau raga merujuk pada seks. ${ }^{6}$

Ada bermacam wujud perbuatan kejahatan yang dicoba, semacam yang sudah dituturkan di atas. Prostitusi masuk ke dalam tipe perbuatan kejahatan kesusilaan ialah penggolongannya diatur dalam Buku Hukum Hukum Kejahatan (KUHP) pada Ayat XIV Novel ke-II ialah diawali dari artikel 289 hingga dengan artikel 296 Buku Hukum Hukum Kejahatan, dalam artikel 289 Buku Hukum Hukum Kejahatan menata hal kesalahan kepada kesusilaan lazim, ialah dengan bahaya ganjaran 9 tahun bui. ${ }^{7}$

Artikel 64 Bagian (1) serta (3) Hukum No 35 Tahun 2014 mengenai Proteksi Anak menata mengenai pantangan aksi asusila kepada anak. Dimana bahaya kejahatan kepada aksi itu diatur pada Artikel 82 Bagian (1) ganjaran yang bisa dikenakan 5 (5) sampai 15 (5 simpati) tahun bui dengan kompensasi sampai $\mathrm{Rp} 5$. 000.000.000,00 (5 miliyar), tetapi bila prostitusi dicoba oleh orang terdekat korban semacam orang berumur, pengajar, penjaga, serta serupanya hingga pidananya ditambah 1 atau 3 (sepertiga) dari yang itu tadinya.

Perbuatan kejahatan intim dapat terjalin pada siapapun tidak lain anak, semacam perbuatan kejahatan prostitusi yang dicoba oleh anak kepada anak. Perbuatan kejahatan intim merupakan seluruh berbagai wujud sikap yang berkonotasi intim yang dicoba dengan cara sepihak serta tidak diharapkan oleh orang yang jadi target alhasil memunculkan respon minus, rasa malu, marah, tersindir pada diri orang yang jadi korban pelecehan intim itu. Pelecehan intim merupakan sikap pendekatan- pendekatan yang terpaut dengan seks yang di idamkan tercantum permohonan buat melaksanakan seks, serta sikap yang lain yang dengan cara lisan atau raga merujuk pada seks. ${ }^{8}$

Bagi Sutanto, kekerasan anak merupakan perlakuan orang berusia ataupun anak yang lebih berumur dengan memakai kewenangan ataupun otoritasnya kepada anak yang tidak berakal yang sepatutnya mejadi tanggung jawab ataupun pengasuhnya yang berdampak beban, kesenggsaraan, cacat ataupun kematian. Kekerasan anak lebih bertabiat selaku wujud

\footnotetext{
${ }^{5}$ P.A.F. Lamintang dan Theo Lamintang, Delik-Delik Khusus Melanggar Norma Kesusilaan dan Norma Kepatutan, Sinar Grafika, Jakarta, 2011, hlm.1.

${ }^{6}$ https://id.m.wikipedia.org/wiki/Pelecehan_Seksual Senin, diakses tanggal 3 Juli 2021.

${ }^{7}$ Philipus M Hadjon, Perlindungan Hukum bagi Rakyat Indonesia, Bina Ilmu, Surabaya, 1987, hlm 12.

${ }^{8}$ Wadong, M. H., Advokasi dan Hukum Perlindungan Anak, Grasindo, Jakarta, 2000, hlm 17.
} 
penganiayaan raga dengan adanya ciri ataupun cedera pada badan si anak. ${ }^{9}$ Kekerasan kepada anak merupakan salah satu permasalahan yang sangat berkuasa serta banyak ditemukan dimanapun, nyaris di tiap tempat di semua provinsi. ${ }^{10}$ Kekerasan kepada anak apapun wujudnya, mulai dari penelantaran, pemanfaatan, dikriminasi hingga pada perlakuan yang tidak kemanusiaan hendak terekam dalam alam dasar siuman mereka sampai beranjak berusia apalagi selama hidupnya. ${ }^{11}$

Dialog mengenai anak serta perlindungannya tidak hendak sempat menyudahi selama asal usul kehidupan, sebab anak merupakan angkatan penerus bangsa serta penerus pembangunan, ialah angkatan yang direncanakan selaku poin eksekutif pembangunan yang berkepanjangan serta pemegang kontrol era depan sesuatu negeri, tidak lain indonesia. Proteksi anak Indonesia berarti mencegah kemampuan pangkal energi insani serta membuat orang Indonesia selengkapnya, mengarah warga yang seimbang serta mampu, materil kebatinan bersumber pada Pancasila serta UUD 1945. ${ }^{12}$

Hukum Bawah Negeri Republik Indonesia Tahun 1945 Artikel 28B bagian (2) menata dengan cara jelas hal hak tiap anak atas kesinambungan hidup, berkembang serta bertumbuhnya dan berkuasa atas proteksi dari kekerasan serta pembedaan. Kejelasan hukum butuh di upayakan untuk kesinambungan proteksi anak serta menghindari kecurangan yang bawa dampak minus yang tidak di idamkan dalam penerapan aktivitas proteksi anak ${ }^{13}$.

Kenaikan permasalahan prostitusi kepada anak yang lalu bertambah meyakinkan kalau petugas penegak hukum wajib jelas melempangkan hukum terpaut permasalahan kekerasan intim yang mengenai anak di dasar baya, alhasil bisa memunculkan dampak kapok untuk para pelakon. ${ }^{14}$ Buat itu aplikasi ganjaran kejahatan yang cocok jadi salah satu usaha buat membagikan proteksi untuk korban sebab proteksi hukum kepada korban haruslah tiba dari bermacam pihak, alhasil menjamin kesehatan psikologis paling utama serta pula raga korban ke depannya. Semacam pada tetapan Tetapan No 154 atau Pid. Sus atau 2018 atau PN. Lbb dan Tetapan No 49 atau Pid. Sus atau 2019 atau PN. Lbb ada perbandingan oleh Juri dalam mempraktikkan kejahatan dengan permasalahan serupa ialah prostitusi kepada anak.

\section{METODE PENELITIAN}

Spesifikasi penelitian adalah deskriptif analitis, dengan metode pendekatan yuridis normative didukung oleh yuridis empiris. Jenis data yang digunakan adalah data sekunder dan data primer. Data sekunder diperoleh dari studi dokumen, data primer diperoleh dengan cara wawancara. Data yang diperoleh kemudian dianalisa secara kualitatif.

\footnotetext{
${ }^{9}$ Sutanto, Kajian Kriminologi Kajahatan Kekerasan Terhadap Wanita, PKBI, Yogyakarta, 2006, hlm
} 51.

${ }^{10}$ Romli Atmasasmita, Peradilan Anak di Indonesia, Mandar Maju, Bandung, 1995, hlm 165.

${ }^{11}$ Haedar Nasir, Agama dan Krisis Kemanusiaan Modern, Cetakan Ke-I, Pustaka Pelajar, Yogyakarta, 1997, hlm 58 .

${ }^{12}$ Nashriana, Perlindungan Hukum Pidana Bagi Anak Di Indonesia, Raja Grafindo Persada, Jakarta, 2012, hlm 1

${ }_{13}$ Arief Gosita, Masalah Korban Kejahatan, Akademika Pressindo, Jakarta, 1993, hlm 222.

14 Khairida, Syahrizal, \& Din, M. Penegakkan Hukum terhadap Pelaku Tindak Pidana Pelecehan Seksual pada Anak dalam Sistem Peradilan Jinayat, Syiah Kuala Law Jurnal, (2017). 1(2), 169-186. Retrieved from http://www.jurnal.unsyiah.ac.id/SKLJ/article/view/8472 diakses pada tanggal 12 Juli 2021. 


\section{PEMBAHASAN}

\section{A. Penerapan Pidana Terhadap Tindak Pidana Kesusilaan Dengan Korban Anak Dibawah Umur Pada Putusan Nomor 154/Pid.Sus/2018/PN.Lbb Dan Putusan Nomor 49/Pid.Sus/2019/PN.Lbb.}

Ada pula unsur-unsur yang ada dalam Artikel 81 (2) Undang-Undang Nomor 23 Tahun 2002 mengenai Proteksi Anak ialah:

1. Faktor tiap orang;

Hal Faktor Tiap Orang, Menimbang, kalau yang diartikan dengan tiap orang dalam masalah ini merupakan siapa saja berlaku seperti orang selaku poin hukum yang di duga melaksanakan sesuatu perbuatan kejahatan tanpa lain diri tersangka Nasrul, pgl. Cowok Datuak yang dituntut dan dimohon pertanggungjawaban atas perbuatannya.

Dengan diajukan nya tersangka ke sidang dalam masalah ini bukti diri nya selaku mana tertera dengan cara nyata serta komplit dalam pesan cema penggugat biasa, perihal mana sudah dibenarkan saksi-saksi serta tersangka serta sepanjang sidang tersangka bisa menanggapi dengan cara bagus serta mudah atas persoalan yang diajukan kepadanya, alhasil orang yang didakwa melaksanakan perbuatan kejahatan begitu juga dalam cema penggugat biasa tidak galat diajukan ke sidang serta tersangka bisa dimohon pertanggungjawaban atas perbuatannya, hingga dengan begitu faktor tiap orang sudah terkabul.

2. Faktor dengan terencana melaksanakan kecoh muslihat, serangkaian dusta, ataupun ajak anak melaksanakan persetubuhan dengannya ataupun dengan orang lain. Sedangkan hukuman lainnya bagi KUHP pasal 287 dan 292 mengatakan bahwa masa hukuman terhadap pelakon pencabulan terhadap anak maksimal 9 tahun (pasal 287) dan maksimal 5 tahun (pasal 292) hal ini menunjukan bahwa 53 hukum proteksi anak selaku lex specialis memberikan ancaman yang lebih besar dibanding dengan yang diatur dalam KUHP. Determinasi itu ada di dalam Artikel 80 bagian (1), (2), serta (3) begitu juga itu di dasar ini: Setiap orang yang melanggar ketentuan sebagaimana dimaksud dalam artikel 76C yang bersuara:

1) Tiap orang dilarang menaruh, membiarkan, melaksanakan, memerintahkan melaksanakan, ataupun ikut dan melaksanakan kekerasan kepada anak. Dipidana dengan kejahatan bui sangat lama 3 (3) tahun 6 (6) bulan serta atau atau kompensasi paling banyak Rp 72.000.000,00 (7 puluh 2 juta rupiah).

2) Dalam hal anak begitu juga dimaksud dalam ayat (1) cedera berat, maka pelaku dipidana dengan pidana penjara sangat lama 5 (5) tahun serta atau ataupun denda paling banyak Rp 100.000.000,00 (seratus juta rupiah).

3) Dalam hal anak begitu juga dimaksud pada ayat (2) mati, maka pelaku dipidana dengan pidana penjara paling lama 15 (5 simpati) tahun serta atau ataupun kompensasi sangat banyak Rp 3.000.000.000, 00 ( tiga miliyar rupiah).

Perbuatan kejahatan kekerasan intim kepada anak ialah masalah yang amat sungguh-sungguh. Kekerasan intim kepada anak tidak cuma hendak memunculkan akibat yang dengan cara raga namun pula akibat dengan cara psikologis. 
Akibat dengan cara raga tidak menginginkan durasi yang sangat lama buat mengobatinya, namun akibat dengan cara psikologis umumnya menginginkan durasi bertahun-tahun supaya bisa membaik semacam sediakala. Apalagi, terdapat juga yang hingga hadapi permasalahan kebatinan ataupun tekanan mental apalagi hingga menyudahi buat bunuh diri dikarena tidak kokoh menahan beban dan rasa malu dampak pelecehans intim yang dirasakannya.

kepada tersangka Nasrul Pgl. Cowok Datuak yang melaksanakan perbuatan kejahatan prostitusi kepada anak di dasar baya dimohon pertanggungjawaban kejahatan bersumber pada Artikel 81 (2) Hukum R. I. Nomor. 23 Tahun 2002 mengenai Proteksi Anak, Artikel 332 bagian (1) KUHP serta Hukum No 48 Tahun 2009 mengenai Kewenangan Peradilan dan peraturan lain. Dalam perihal ini dimintakan pertanggungjawabannya cocok dengan perbuatannya itu pada saat pada umumnya kondisi jiwanya:

1. Tidak tersendat oleh penyakit lalu menembus ataupun sedangkan (temporair)

2. Tidak cacat dalam perkembangan (bisu, imbesil)

3. Tidak tersendat sebab kaget, hynotisme, kemarahan yang meluap, akibat dasar siuman atau reflexe, berceloteh sebab meriang.

Tetapan dalam masalah tersebut diatas sudah cocok dengan determinasi bagus hukum kejahatan formil ataupun hukum kejahatan materil serta ketentuan bisa dipidananya seseorang tersangka, perihal ini didasarkan pada pengecekan dalam sidang, dimana perlengkapan fakta yang diajukan oleh Beskal Penggugat Biasa, tercantum di dalamnya penjelasan saksi yang silih berpadanan ditambah dengan penjelasan tersangka yang membenarkan dengan cara jujur aksi yang dikerjakannya dan perlengkapan fakta berbentuk pesan hasil Visum yang menguatkan atas kesalahan tersangka. Tetapi nyatanya visum yang dipakai telah amat lama sekali, alhasil diragui keabsahannya. Aksi tersangka pada kedua tetapan itu bertabiat melawan hukum serta tidak ada alibi pembenar. tersangka pula merupakan orang yang bagi hukum sanggup bertanggung jawab serta ia melaksanakan aksi dengan terencana dan tidak terdapat alibi toleran. Alhasil dengan begitu tetapan badan juri yang membagikan pemidanaan telah pas.

Dalam permasalahan ini Artikel yang didakwakan pada tersangka sudah cocok dimana korban hadapi guncangan kejiwaan serta hancurnya derajat dan era depan 2 orang anak wanita yang sedang dibawah baya karena akibat sangat besar dari aksi tersangka yakni sudah melenyapkan kegadisan dari kedua korbannya yang sedang di dasar baya, yang sudah dibuktikan oleh hasil pesan Visum yang melaporkan kalau kedua korban hadapi sobekan epidermis cewek dampak barang tumpul yang melaporkan kalau epidermis cewek tidak utuh lagi (tidak gadis). Tidak hanya itu para korban pula merasakan sakit serta melilit pada perlengkapan kelaminnya serta membaik sehabis sebagian hari dengan lewat pemeliharaan serta pengobatan oleh dokter alhasil bisa pula diklaim selaku dampak dari kekerasan intim.

Bersumber pada hasil riset pengarang lewat analisa hasil tetapan serta materi daftar pustaka, fakta-fakta yang terbongkar dipersidangan cocok dengan posisi permasalahan, penjelasan saksi, penjelasan pakar ialah perlengkapan fakta yang legal semacam pesan hasil Visum et Repertum begitu juga dijabarkan diatas, hingga apabila 
satu dengan yang yang lain silih dihubungkan, ditemui fakta-fakta yang membuktikan kalau semua unsur- unsur dari cema Beskal Penggugat Biasa sudah terkabul. Alhasil dengan begitu tetapan atau kesimpulan Badan Juri yang melaporkan kalau tersangka sudah teruji dengan cara legal serta memastikan melaksanakan perbuatan kejahatan prostitusi kepada anak dibawah baya yang didakwakan.

Pada Tetapan No 154 atau Pid. Sus atau 2018 atau PN. Lbb Juri mempraktikkan kejahatan yang ada pada Artikel 76D juncto Artikel 81 bagian (1) Hukum Republik Indonesia No 35 Tahun 2014 Mengenai Pergantian Atas Hukum No 23 Tahun 2002 Mengenai Proteksi Anak. Pada Bagian Memeriksa Juri melaporkan tersangka teruji dengan cara legal serta memastikan bersalah melaksanakan perbuatan kejahatan Melaksanakan Kekerasan Memforsir Anak Melaksanakan Persetubuhan. Perihal ini cocok Dengan cema Primair dari Beskal penggugat Biasa. Atas aksi itu kejahatan yang dijatuhkan merupakan Bui sepanjang: 8 (8) tahun serta 6 (6) bulan, serta kejahatan Kompensasi beberapa Rp.10.000.000 (10 juta rupiah), dengan determinasi bila kejahatan Kompensasi itu tidak dibayar hingga ditukar dengan kejahatan Kurungan sepanjang 6 (6) bulan.

Sebaliknya pada Tetapan No 49 atau Pid. Sus atau 2019 atau PN. Lbb bersumber pada pengecekan peradilan penuhi faktor yang serupa ialah ada pada Artikel 81 bagian (1) Jo Artikel 76D Hukum No 35 tahun 2014 mengenai Pergantian atas Hukum No 23 tahun 2002 mengenai Proteksi Anak. Juri mempraktikkan kejahatan berbentuk kejahatan bui sepanjang 7 (7) tahun serta kejahatan kompensasi sebesar Rp.10.000.000,- (10 juta rupiah) dengan determinasi bila kejahatan kompensasi itu tidak dibayar hingga ditukar dengan kejahatan kurungan sepanjang 6 (6) bulan. Dari kedua tetapan majelis hukum yang ditemukan, nampak kejahatan yang dijatuhkan oleh juri pula bermacam- macam bagus ganjaran bui ataupun kompensasi yang diaplikasikan. Hendak namun tetapan itu tidak beraturan walaupun tipe perbuatan pidananya merupakan serupa.

Kejahatan yang diaplikasikan pada hukum proteksi anak bertabiat komulatif, sebab konsepnya memakai tutur "serta" pada sanksinya. Walaupun kejahatan kompensasi dicantumnya jauh lebih besar nilainya dibanding dengan kejahatan bui, namun tidak dimungkinkan buat diaplikasikan dengan cara maksimum kepada orang perseorangan, sebab tiap tetapan majelis hukum senantiasa melibatkan kejahatan pengganti kepada peranan melunasi kompensasi yang dijatuhkan ialah "dengan determinasi bila kompensasi itu tidak sanggup dibayarkan hingga ditukar dengan kejahatan kurungan selaku pengganti kejahatan kompensasi” serta memandang watak kejahatan kurungan hingga maksimum cuma satu tahun yang bisa diaplikasikan.

Penjatuhan kompensasi pada permasalahan Tetapan No 154 atau Pid. Sus atau 2018 atau PN. Lbb serta tetapan no 49 atau Pid. Sus atau 2019 atau PN. Lbb yang dimana tersangka dibebani kompensasi sebesar Rp.10.000.000,- (10 juta rupiah) bersumber pada pada Artikel 82 bagian (1) jo Artikel 76E UURI No 35 tahun 2014 mengenai Pergantian Undang Undang No 23 tahun 2002 mengenai Proteksi Anak. Pada Artikel 82 bagian (1) melaporkan determinasi kejahatan kompensasi maksimum Rp.5.000.000.000,- (5 milyar rupiah). Bersumber pada penjelasan pada Artikel 82 bagian (1) pengarang menyangka pembebanan kejahatan kompensasi sangat besar dimana pada faktanya mayoritas tersangka lebih memilah menempuh ganjaran penganti kompensasi dengan kejahatan bui di 
bandingkan melunasi kompensasi yang di bebani pada tersangka. Penjatuhan kejahatan kompensasi hendaknya tidak memuat angka yang besar tetapi di samakan dengan ekonomi warga pada biasanya alhasil kejahatan kompensasi bisa senantiasa berjalan keefektivitasannya serta tidak cuma jadi sesuatu penjatuhan ganjaran yang pada biasanya hendak digantikan dengan kejahatan kurungan tanpa mempertimbangkan ubah cedera pada korban. Penjatuhan kompensasi hendaknya, meski dikira kecil ataupun sedikit dalam kisaran kejahatan kompensasi tetapi kejahatan kompensasi itu senantiasa dijalani oleh tersangka ataupun dengan tutur lain senantiasa membagikan ubah cedera pada korban serta penjatuhan ganjaran kompensasi senantiasa dibilang terlaksana.

\section{B. Pertimbangan Hakim Terhadap Tindak Pidana Kesusilaan Dengan Korban Anak Dibawah Umur Pada Putusan Nomor 154/Pid.Sus/2018/PN.Lbb Dan Putusan Nomor 49/Pid.Sus/2019/PN.Lbb}

Dengan diajukan nya tersangka ke sidang dalam masalah ini bukti diri nya selaku mana tertera dengan cara nyata serta komplit dalam pesan cema penggugat biasa, perihal mana sudah dibenarkan saksi-saksi serta tersangka serta sepanjang sidang tersangka bisa menanggapi dengan cara bagus serta mudah atas persoalan yang diajukan kepadanya, alhasil orang yang didakwa melaksanakan perbuatan kejahatan begitu juga dalam cema penggugat biasa tidak galat diajukan ke sidang serta tersangka bisa dimohon pertanggungjawaban atas perbuatannya, hingga dengan begitu faktor tiap orang sudah terkabul.

Keadaan Yang Dicermati Dalam Estimasi Juri Dalam Tetapan Tetapan No 154 atau Pid. Sus atau 2018 atau Pn. Lbb. Tidak hanya memikirkan keadaan yang memudahkan serta membebankan tersangka, juri pula memikirkan perihal yang berhubungan dengan kekeliruan yang dicoba oleh tersangka. Kekeliruan dipecah jadi 2 bagian ialah kesengajaan serta kealpaan. Dalam permasalahan ini nyata kalau tersangka melaksanakan perbuatannya dengan terencana, oleh sebab itu terpenuhilah faktor kesalahannya. Dalam permasalahan ini tindakan hati dari pelakon dikala melaksanakan perbuatannya tidak dalam kondisi dituntut, terhimpit ataupun dalam akibat obat-obatan, maksudnya pelakon dengan cara siuman melaksanakan perbuatannya.

Dalam perihal ini juri tidak memikirkan corak sesungguhnya dari pelakon sebab dalam kesaksiannya pelakon tidak cuma membuktikan perlengkapan kemaluan tersangka pada korban tetapi pula luang memasukkan jemari kedalam alat kelamin dari korban yang dapat saja tujuan dari pelakon merupakan mau memperkosa korban. Juri memikirkan gimana tersangka melaksanakan perbuatannya itu, sebab dengan mengenali metode yang dicoba tersangka itu juri bisa mengenali apa saja yang terjalin alhasil bisa jadi estimasi juri dalam menjatuhkan ganjaran kepada tersangka. Dalam keadaan yang memudahkan, juri memikirkan umur tersangka yang telah berumur, serta didalam sidang tersangka bertabiat bagus. Dalam keadaan yang membebankan tersangka, pengarang beranggapan kalau juri lebih menitik-beratkan pada aksi tersangka, ialah aksi tersangka menggelisahkan warga dimana anak yang sedang dibawah baya selaku korban dari perbuatan kekerasan intim. Sehubungan dengan itu, Badan hendak meninjau apakah betul Cema Pengganti Pertama itu sudah bisa dibuktikan dengan cara syah bagi hukum serta memastikan oleh Penggugat Biasa ataukah tidak. Mengenai unsur-unsur; 


\section{Faktor awal tiap orang;}

Penafsiran "tiap orang" begitu juga determinasi artikel 82 bagian 1 Hukum Repubik Indonesia No 35 Tahun 2014 mengenai pergantian atas Hukum No. 23 tahun 2002 mengenai Proteksi Anak. tiap orang merupakan serupa dengan terminologi tutur "benda siapa". Jadi yang diartikan dengan“ tiap orang" disini merupakan tiap orang ataupun individu yang ialah subyek hukum yang melaksanakan sesuatu aksi kejahatan ataupun subyek pelakon dari pada sesuatu aksi kejahatan yang bisa dimintai pertanggungjawaban atas seluruh tindakannya.

Bersumber pada perihal itu hingga jelaslah kalau penafsiran "tiap orang" yang diartikan faktor ke-1 dari artikel yang terdapat Pesan Cema Penggugat Biasa merupakan tersangka Nasrul Pgl. Cowok Datuak. Tetapi, buat memutuskan apakah betul tersangka itu subyek pelakon dari pada sesuatu aksi kejahatan dalam masalah ini sedang butuh dibuktikan apakah tersangka itu betul sudah melaksanakan sesuatu susunan aksi laris aksi begitu juga yang didakwakan. Bila betul tersangka melaksanakan sesuatu susunan aksi laris aksi yang penuhi seluruh unsur-unsur dari artikel Hukum hukum kejahatan yang didakwakan, hingga dengan sendirinya faktor "tiap orang" itu sudah terkabul kalau tersangka merupakan pelakon dari aksi kejahatan dalam masalah ini;

2. Faktor kedua dilarang atau mengancam

Dilarang melaksanakan kekerasan ataupun bahaya kekerasan, memforsir, melaksanakan kecoh muslihat, melaksanakan serangkaian dusta, ataupun ajak Anak buat melaksanakan ataupun membiarkan dicoba aksi asusila kalau hal faktor ke-2 di atas ialah "Dilarang melaksanakan kekerasan ataupun bahaya kekerasan, memforsir, melaksanakan kecoh muslihat, melaksanakan serangkaian dusta, ataupun ajak Anak buat melaksanakan ataupun membiarkan dicoba aksi asusila" Badan hendak memikirkan selaku selanjutnya;

Bersumber pada pertimbangan-pertimbangan itu, Badan beranggapan faktor ke2 di atas sudah terkabul terdapatnya oleh susunan aksi tersangka. Pertimbanganpertimbangan itu di atas, ialah dengan terpenuhinya faktor ke-2, dapatlah disimpulkan kalau tersangka sudah melaksanakan susunan aksi laris aksi begitu juga yang tertera dalam unsur-unsur dari artikel Hukum hukum kejahatan yang didakwakan kepadanya pada Cema Pengganti Pertama, Alhasil oleh sebab itu sudah terkabul pula faktor ke-1 "benda siapa" kalau betul tersangka selaku pelakon dari aksi kejahatan yang sudah didakwakan oleh Penggugat Biasa pada Cema Pengganti Pertama; permohonan perkataan tersangka didepan sidang yang pada pokoknya harap kelapangan ganjaran sebab merasa menyesal sudah melaksanakannya dan berkomitmen tidak hendak mengulanginya lagi, Badan hendak menentukannya dalam amar tetapan ini. Aksi tersangka yang sudah teruji itu bagi hukum merupakan kesalahan. Sebab aksi tersangka sudah teruji dengan cara legal bagi hukum serta memastikan, hingga kepadanya wajib diklaim bersalah serta karenanya itu telah adil pula dijatuhi kejahatan yang setimpal dengan kesalahannya, sebab selama pengecekan di sidang pada durasi tersangka melaksanakan aksi itu dalam kondisi siuman.

Mengenai estimasi pula dimaksudkan buat memandang penjatuhan ganjaran oleh Badan Juri atas penjatahan cema yang dituntutkan tercantum tipe cema tunggal ataupun pengganti. Tujuan pemidanaan pada dikala ini bukanlah sekedar cuma memidana orang yang bersalah, hendak namun pula bermaksud buat ceria supaya 
tersangka yang berhubungan bisa insyaf serta kembali pada jalur yang betul dan bisa pula membagikan proteksi pada warga pada biasanya dari perbuatan-perbuatan begitu juga yang sudah dicoba tersangka. Bersumber pada pertimbangan- pertimbangan itu, hingga Badan beranggapan sudah pas serta seimbang rasanya kejahatan yang dijatuhkan kepada diri tersangka merupakan begitu juga yang hendak didetetapkan dalam amar tetapan ini. Hasil atas era penahanan serta ataupun penangkapan yang sudah dijalani tersangka saat sebelum perkaranya diputus cocok dengan determinasi artikel 22 bagian (4) KUHAP hendak dikurangkan segenap dari kejahatan yang dijatuhkan itu. Oleh sebab itu tersangka di kuat dalam narapidana RUTAN, hingga lumayan alibi untuk Badan buat menginstruksikan pada tersangka biar senantiasa terletak dalam narapidana sampai tetapan ini memiliki daya hukum senantiasa.

Sebab nyatanya kepunyaan saksi korban serta bukan selaku beberapa barang corpora delictie, hingga Badan beranggapan kalau benda fakta itu haruslah dikembalikan pada saksi korban. tersangka diklaim bersalah serta dijatuhi kejahatan, hingga cocok dengan determinasi artikel 222 bagian 1 KUHAP pada tersangka wajib pula dibebani buat melunasi beaya masalah yang besarnya hendak didetetapkan dalam amar tetapan ini. Estimasi dicocokkan cema yang diajukan beskal, hingga juri menyudahi kepada tersangka Cowok Datuak teruji melaksanakan perbuatan kejahatan prostitusi kepada Nuri berumur 17 tahun 8 bulan, dan tersangka Cowok Datuak sudah membenarkan aksi asusila yang dicoba pada Nuri. Estimasi dari cema itu juri memandang gimana wujud cema yang diresmikan serta ganjaran lain yang cocok dengan peraturan perundangundangan. Mengenai peringanan serta pemberatan ganjaran juri menimbang dari kenyataan dikala di sidang sebenarnya tersangka amat kooperati serta jujur dalam sidang berjalan.

Pengumpulan ketetapan amatlah dibutuhkan oleh juri dalam membuat ketetapan yang hendak dijatuhkan pada tersangka. Estimasi juri dalam menjatuhkan tetapan sehabis cara pengecekan serta sidang berakhir, hingga juri wajib mengambil ketetapan yang cocok. Perihal ini amat butuh buat menghasilkan tetapan yang sepadan serta mendekati rasa kesamarataan, bagus itu dari bidang pelakon perbuatan kejahatan, korban perbuatan kejahatan, ataupun warga. Buat itu saat sebelum menjatuhkan ganjaran kejahatan, juri melaksanakan aksi untuk mengamati terlebih dulu mengenai bukti insiden yang diajukan kepadanya dengan memandang bukti- bukti yang terdapat (kenyataan sidang) serta diiringi keyakinannya sehabis itu memikirkan serta membagikan evaluasi atas insiden yang terjalin dan menghubungkannya dengan hukum yang legal. Berikutnya Badan Juri mengutip kesimpulan dengan memutuskan sesuatu ganjaran kejahatan kepada aksi yang dicoba tersangka. Ada pula perihal yang jadi dasar-dasar estimasi yang dipakai oleh Badan Juri dalam memutuskan masalah wajib cocok kenyataan kenyataan dalam sidang. Pada kedua masalah tidak terdapat perihal estimasi yang meringankan untuk tersangka.

Tidak hanya estimasi yuridis diatas Juri pula memikirkan pandangan sosiologis dari aksi tersangka pada putusannya. Pandangan sosiologis merupakan pandangan diluar dari pandangan hukum yang pula wajib dipikirkan Juri. Pandangan sosiologis bisa ialah pandangan membebankan serta memudahkan yang ada pada aksi serta pada diri tersangka sendiri. Pada Tetapan No Tetapan No 154 atau Pid. Sus atau 2018 atau Pn. 
Lbb ialah terdapatnya kondisi yang membebankan ialah Kalau aksi tersangka lebih dari 1 (satu) kali pada Anak Saksi atau Anak Korban, merupakan telah membidik pada pemanfaatan intim Anak. tersangka dalam perbuatannya sudah menggunakan kondisi Anak Saksi atau Anak Korban, yang bagi. Informasi Sosial Anak Selaku Korban, pada pokoknya menerangkan: Korban memiliki energi pikir yang kurang untuk anak seusianya. Korban kerap mesem sendiri apabila dimohon menceritakan.

Pada sidang tersangka pula mengalutkan pengecekan konferensi dan tidak membenarkan perbuatannya. Estimasi membebankan dengan cara non yuridis itu membuat Juri mempraktikkan kejahatan lebih berat.

Berlainan dengan estimasi yang ada pada tetapan No tetapan No 49 atau Pid. Sus atau 2019 atau Pn. Lbb ada estimasi sosiologis. estimasi sosiologis yang dicermati Juri merupakan Aksi tersangka melanggar norma yang legal dalam warga, bagus norma hukum, norma kesusilaan ataupun norma agama serta tersangka membenarkan perbuatannya. Kondisi yang memudahkan tersangka berlagak santun dalam persidangan.

\section{PENUTUP}

Hakim dalam keputusannya terhadap tindak pidana pencabulan dengan korban anak dapat membuat keputusan yang berat sehingga betul betul dapat melindungi kepentingan anak. Agar pembuat kebijakan dapat melakukan perubahan atas ketentuan pidana bagi anak tersebut dengan memasukan pidana tambahan berupa pengganti kerugian bagi anak korban.

\section{DAFTAR PUSTAKA}

Wirjono Projodikoro, Tindak Pidana Tertentu di Indonesia, Refika Aditama, Bandung, 2003

Suteki, Desain Hukum di Ruang Sosial, Thafa Media, Yogyakarta, 2013

Hari Saherodji, Pokok-Pokok Kriminologi, Aksara Baru, Jakarta, 1980

Andi Hamzah, Suatu Tinjauan Ringkas Sistem Pemidanaan di Indonesia, Akademika Pressindo, Jakarta, 1999

P.A.F. Lamintang dan Theo Lamintang, Delik-Delik Khusus Melanggar Norma Kesusilaan dan Norma Kepatutan, Sinar Grafika, Jakarta, 2011

Philipus M Hadjon, Perlindungan Hukum bagi Rakyat Indonesia, Bina Ilmu, Surabaya, 1987

Wadong, M. H., Advokasi dan Hukum Perlindungan Anak, Grasindo, Jakarta, 2000

Sutanto, Kajian Kriminologi Kajahatan Kekerasan Terhadap Wanita, PKBI, Yogyakarta, 2006

Romli Atmasasmita, Peradilan Anak di Indonesia, Mandar Maju, Bandung, 1995

Haedar Nasir, Agama dan Krisis Kemanusiaan Modern, Cetakan Ke-I, Pustaka Pelajar, Yogyakarta, 1997 
Nashriana, Perlindungan Hukum Pidana Bagi Anak Di Indonesia, Raja Grafindo Persada, Jakarta, 2012.

Arief Gosita, Masalah Korban Kejahatan, Akademika Pressindo, Jakarta, 1993

Khairida, Syahrizal, \& Din, M. Penegakkan Hukum terhadap Pelaku Tindak Pidana Pelecehan Seksual pada Anak dalam Sistem Peradilan Jinayat, Syiah Kuala Law Jurnal, (2017). 1(2), 169-186. Retrieved from http://www.jurnal.unsyiah.ac.id/SKLJ/article/view/8472 